\title{
PERATURAN DAERAH, ANTARA KEPENTINGAN PEMERINTAH PUSAT DAN PEMERINTAH DAERAH
}

\author{
Supriyadi \\ Fakultas Hukum Universitas Merdeka Malang \\ Jl. Terusan Raya Dieng No. 62-64 Malang \\ Supriyadi@unmer.ac.id
}

\begin{abstract}
ABSRTACT
Regional Regulation as one of law regulation product is an instrument for regulate government matters that include in regional autonomy matters. Specially for Municipal or City Law Regulation, regulating authority is held on Municipal or City House of Representatives and its leader. Normatively, the existence of Municipal or City Regulation is form to regulate about the providence govermental business that include in regional autonomy, despite from expose the higher law regulation, and regulate the unique character of the regional that depends on law and norms. The enforcement of the law regulation is expected to be a mean to perceive national policy and government development program in order to reach national goal. Practically, it is not close chances that the law regulation from regional formed is not relevant with natiional goal. When that happened, Ministry of Domestic Affair and Governor can directly cancel the irrelevant law regulation, unless Constitutional Court cancel that authority, Central government no longer has authority to cancel it. It is has to be done by an assesment through Judicial Review under Supreme Court. This condition could be an obstacle in development accelerate, especially in economic sector in term of creating business and investment in regional area.
\end{abstract}

Keywords: Regional Regulation, Regional Autonomy, Judicial Review.

\begin{abstract}
ABSTRAK
Peraturan daerah (perda) sebagai salah satu produk hukum daerah merupakan instrumen bagi daerah untuk mengatur urusan pemerintahan yang menjadi urusan rumah tangganya (otonomi daerah). Khusus untuk Perda kabupaten/kota, kewenangan pembentukannya berada ditangan DPRD kabupaten/kota dan bupati/ walikota. Secara normatif, keberadaan perda kabupaten/kota dibentuk untuk mengatur penyelenggaraan urusan pemerintahan yang menjadi otonomi daerah, selain menjabarkan ketentuan peraturan perundang-undangan yang lebih tinggi, serta mengatur muatan lokal/kekhasan daerah dengan berpedoman pada peraturan perundang-undangan yang lebih tinggi, kepentingan umum, dan kesusilaan. Keberadaan perda kabupaten/kota juga diharapkan menjadi sarana untuk menterjemahkan kebijakan nasional dan program pembangunan nasional dalam rangka mempercepat terwujudnya tujuan nasional. Secara praktis, tidak menutup kemungkinan perda yang dihasilkan kebupaten/kota tersebut oleh Pemerintah Pusat dinilai tidak sejalan dengan kebijakan nasional dan program Pemerintah Pusat. Jika hal ini terjadi, Menteri Dalam Negeri dan/atau gubernur sebagai wakil Pemerintah Pusat dapat langsung membatalkan perda kabupaten/kota yang sudah diberlakukan di masyarakat. Kecuali jika diuji di MK dan MK membatalkan kewenangan tersebut, maka Pusat tidak punya kewenangan lagi untuk membatalkan secara langsung perda kabupaten/kota yang dinilai bertentangan, tetapi harus lewat pengujian di Mahkamah Agung melalui judicial review. Tentu keadaan ini oleh Pusat dirasa menjadi kendala untuk akselerasi program pembangunan, khususnya di bidang ekonomi terutama dalam penciptaaan iklim usaha dan investasi di daerah.
\end{abstract}

Kata Kunci: Otonomi Daerah, Peraturan Daerah, Uji Materi. 
Di satu sisi Indonesia sebagai negara kesatuan dengan sistem pemerintahan presidensiil berpegang pada prinsip bahwa concentration of power and responsibility upon the Presiden, bahwa segala kekuasaan dalam wilayah negara kesatuan yang di dalamnya meliputi daerah-daerah otonom, pada dasarnya berada di tangan Pemerintah Pusat (Presiden) dan tanggung jawab terakhir dalam penyelenggaraan pemerintahan negara, termasuk di dalamnya penyelenggaraan pemerintahan daerah berada di tangan Presiden. Sementara di sisi lain Indonesia juga memberlakukan otonomi bagi Daerah baik provinsi maupun kabupaten/kota untuk menjalankan pemerintahan daerah berdasarkan kepentingan masyarakat setempat.

Harapannya kedua pemerintahan, di Pusat dan Daerah dapat berjalan seiring dalam mewujudkan tujuan negara. Sebagai negara hukum, semua rencana dan kebijakan Pemerintah Pusat dituangkan ke dalam produk hukum dalam bentuk undang-undang dan peraturan pelaksanaannya yang bersumber pada legislative power dan ехесutive power. Sementara Daerah sebagai bagian dari wilayah Negara Kesatuan Republik Indonesia (NKRI), rencana dan kebijakannya yang dituangkan ke dalam produk hukum dalam bentuk peraturan daerah (Perda) harus sejalan dengan kebijakan Pusat.

Atas dasar itulah Undang-Undang Nomor 23 Tahun 2014 tentang Pemerintahan Daerah, khususnya Pasal 251 menentukan kewenangan Menteri Dalam Negeri (Mendagri) untuk membatalkan perda provinsi dan peraturan gubernur serta kewenangan gubernur sebagai wakil Pemerintah Pusat untuk membatalkan perda kabupaten/kota dan peraturan bupati/walikota jika bertentangan dengan ketentuan peraturan perundang-undangan yang lebih tinggi, kepentingan umum, dan/atau kesusilaan.

Berdasarkan Pasal 251 tersebut, pada bulan Juni 2016 Pemerintah Pusat telah membatalkan 3.143 perda. Alasan yang paling menonjol dalam pembatalan 3.143 perda adalah bahwa perdaperda tersebut telah mengganggu iklim ekonomi dan investasi. Memang di satu sisi Pemerintah Pusat sedang giat-giatnya untuk menciptakan iklim yang kondusif di bidang ekonomi, sementara di sisi lain Daerah juga memiliki kewenangan untuk mengatur segala persolan yang menjadi otonominya.

Kecuali kewenangan untuk membatalkan perda tersebut diajukan judicial review ke MK dan MK mengabulkan permohonan tersebut, sehingga Pemerintah Pusat dalam hal ini Mendagri atau Gubernur selaku wakil Pemerintah Pusat tidak berwenang lagi membatalkan langsung perda Kabupaten/Kota yang sudah berlaku. Dengan kata lain, Mendagri atau Gubernur sebagai wakil Pemerintah Pusat tidak mempunyai kewenangan lagi untuk membatalkan Perda Kabupaten/Kota yang sudah berlaku, pembatalan hanya bisa dilakukan melalui judicial review ke Mahkamah Agung.

Merujuk pada kondisi tersebut, maka laju penataan kebijakan yang dilakukan Pemerintah Pusat dalam rangka mempercepat dan menciptakan iklim usaha dan investasi mulai dari Pusat sampai ke Daerah tentu mengalami hambatan. Pusat tidak bisa lagi semaunya untuk membatalkan perda, khususnya perda kabupaten/kota yang dinilai atau dianggap tidak sejalan dengan keinginan Pusat.

Sebagaimana diketahui bahwa Pemerintahan Jokowo-JK sangat getol untuk memfokuskan pembangunan dalam bidang ekonomi dengan menarik sebanyak-banyaknya investor domestik maupun asing untuk menanamkan modalnya di Indonesia. Salah satu instrumen yang oleh Pemerintah Pusat tidak boleh menghambat penciptaan iklim usaha dan investasi adalah perlunya penyederhanaan pengaturan terutama perda-perda yang diberlakukan di daerah.

\section{Prinsip Negara Kesatuan}

Negara kesatuan terdapat prinsip bahwa pada hakekatnya pemegang tampuk kekuasaan tertinggi 
atas segenap urusan negara ialah pemerintah pusat, meskipun telah ada penyerahan atau pelimpahan kekuasaan kepada pemerintah daerah atau pejabatnya (M. Solly Lubis, 1986, 8). Dalam suatu negara kesatuan, terdapat asas bahwa segenap urusan pemerintahan dalam negara kesatuan tetap merupakan suatu kebulatan (eenheid) dan pemegang kekuasaan tertinggi di negara itu adalah pemerintah pusat.

Kaitannya dengan hal tersebut, sebelum Penjelasan UUD 1945 tidak diberlakukan dengan adanya perubahan keempat UUD 1945, pernah disebutkan dalam penjelasan umum tentang sistem pemerintahan negara bahwa dalam menjalankan pemerintahan negara, kekuasaan dan tanggung jawab adalah di tangan Presiden (concentration of power and responsibility upon the President). Hal itu menunjukkan bahwa dalam negara kesatuan, termasuk di Indonesia hak, kewenangan untuk melakukan kontrol dan penilaian terhadap penyelenggaraan pemerintahan daerah dimiliki oleh pemerintah pusat, dalam hal ini adalah Presiden, ini artinya keberadaan pemerintahan daerah dalam melaksanakan pemerintahan tidak boleh menyimpang dari garis kebijakan Pemerintah Pusat, bahkan Pusat mempunyai kewajiban untuk melakukan pengawasan dan pembinaan terhadap penyelenggaraan otonomi daerah.

Seperti telah ditetapkan dalam Pasal 1 Undang-Undang Dasar Negara Republik Indonesia Tahun 1945 (UUD 1945) bahwa Negara Indonesia ialah negara kesatuan, yang berbentuk republik. Dalam konteks negara kesatuan (unitary state), maka pemerintah nasional atau pusat-lah yang pertama kali dibentuk untuk menjalankan pemerintahan seluruh wilayah negara. Sebagaimana lazimnya dalam negara kesatuan, penyelenggaraan pemerintahan dapat menggunakan sistem sentralisasi atau sistem desentralisasi, tergantung dari efektif tidaknya atau efisien tidaknya penyelenggaraan pemerintahan (R. Joeniarto, 1982, 29). Mengingat wilayah negara Indonesia begitu luas dengan beragam suku, budaya, karakteristik masingmasing daerah, serta kepentingannya, tidak mungkin pemerintahan dijalankan secara efektif dan efisien jika dilaksanakan sendiri oleh Pusat.

Oleh karena itu, dalam Pasal 18 ayat (1) UUD 1945, kemudian dipertegas lagi dalam Pasal 2 Undang-Undang Nomor 23 Tahun 2014, negara Indonesia menganut asas desentralisasi dalam penyelenggaraan pemerintahan, yaitu “Negara Kesatuan Republik Indonesia dibagi atas daerahdaerah provinsi dan daerah provinsi itu dibagi atas kabupaten dan kota, yang tiap-tiap provinsi, kabupaten, dan kota itu mempunyai pemerintahan daerah, yang diatur dengan Undang-undang".

Konsekwensi dari pembagian wilayah daerah tersebut adalah keberadaan daerah provinsi, kabupaten, dan kota dalam menjalankan pemerintahannya tidak boleh lepas, apalagi menyimpang dari kebijakan dan program nasional, meskipun daerah diberikan kewenangan untuk menjalankan pemerintahan daerahnya sendiri, justru sebaliknya kabijakan dan program kerja daerah harus sejalan dan sikron dengan kebijakan nasional. Hal ini dapat dilihat dari alur yang ditarik mulai dari perumusan tujuan nasional yang oleh Pemerintah Pusat kemudian dijabarkan ke dalam rencana pembangunan jangka panjang nasional (RPJPN). RPJPN ini oleh Pemerintah Pusat kemudian ditindak lanjuti ke dalam rencana pembangunan jangka menengah nasional (RPJMN), sedangkan oleh daerah provinsi dan kabupaten/kota menjadi pedoman dalam merumuskan rencana pembangunan jangka panjang daerah (RPJPD). Agar lebih operasional, Pemerintah Pusat menyusun program kerja tahunan dalam bentuk rencana kerja pemerintah (RKP). Sementara daerah dalam menyusun rencana pembangunan jangka menengah daerah (RPJMD) harus merujuk pada dua sumber, yaitu RPJPD dan RPJMN. Begitu juga daerah dalam menyusun program kerja tahunan dalam bentuk rencana kerja pemerintah daerah (RKPD) harus memperhatikan RPJMD dan RKP. Sinkronisasi program kerja 
pemerintahan baik Pusat maupun daerah sebagaimana ditunjukkan dari keterjalinan rencana pembangunan tersebut di atas menunjukkan bahwa keberadaan Pemerintah Pusat dan pemerintahan daerah dalam Negara Kesatuan Republik Indonesia (NKRI) merupakan satu kesatuan yang tak terpisahkan yang berjalan menuju titik yang sama, yaitu terwujudnya tujuan negara atau tujuan nasional. Satu kesatuan dalam negara kesatuan juga harus dimaknai bahwa dalam NKRI hanya ada satu sistem hukum nasional yang berpuncak pada sumber hukum tertinggi, hukum yang ada di bawah harus bersumber dan tidak boleh bertentangan dengan hukum yang ada di atasnya dan seterusnya begitu, any superior legal norm is the source of inferior legal norm (Kelsen, Hans, 1973, 131).

Berdasarkan konsep demikian ini, maka Pusat sangat berkepentingan agar kebijakan yang diambil oleh daerah provinsi, kabupaten, dan kota yang dituangkan dalam bentuk perda maupun peraturan kepala daerah (perkada) harus sejalan dan mendukung kebijakan yang ditetapkan oleh Pemerintah Pusat. Oleh karena itu, fungsi pembinaan dan pengawasan yang dilakukan oleh Pusat kepada daerah menjadi sangat penting agar kebijakan yang dirumuskan di Pusat dan daerah dapat sejalan. Namun hal tersebut tidaklah gampang untuk menyatukan kebijakan dari 34 daerah provinsi dan 514 daerah kabupaten dan kota di Indonesia yang setiap tahunnya selalu menghasilkan puluhan perda dan perkada dalam berbagai bidang sesuai urusan pemerintahan yang menjadi otonomi daerah, dan apabila ada pihak yang mengajukan Judicial Review ke MK dan MK mengabulkan mencabut kewenangan Mendagri dan Gubernur sebagai wakil Pemerintah Pusat untuk membatalkan perda yang dinilai bertentangan dengan peraturan perundang-undangan yang lebih tinggi, kepentingan umum, dan/atau kesusilaan, maka hal ini merupakan persoalan tersendiri apabila perda yang dihasilkan oleh daerah kabupaten dan kota khususnya, terlanjur berlaku di masyarakat, karena pembatalannya harus dilakukan melalui judicial review di Mahkamah Agung, dan prosedur seperti ini tentu tidak mudah bagi Pemerintah Pusat dan juga tidak bisa cepat layaknya pembatalan yang pernah dilakukan pada bulan Juni 2016 ketika Pasal 251 ayat (2), (3), (4), dan ayat (8) Undang-Undang Nomor 23 Tahun 2014 masih belum dinyatakan tidak mempunyai kekuatan mengikat oleh MK.

\section{Hakekat Otonomi Daerah dan Keberadaan Perda}

Pilihan Negara Indonesia dengan menerapkan asas desentralisasi dalam penyelenggaraan pemerintahan tercermin melalui pasal 18 UUD 1945, khususnya ayat (2), yaitu "Pemerintahan daerah provinsi, daerah kabupaten, dan kota mengatur dan mengurus sendiri urusan pemerintahan menurut asas otonomi dan tugas pembantuan". Pengaturan lebih rinci terhadap urusan pemerintahan yang menjadi otonomi daerah berdasarkan asas desentralisasi diatur dalam Undang-Undang Nomor 23 Tahun 2014, khususnya Pasal 5 ayat (4), Pasal 9 ayat (4), dan Pasal 12.

Dipilihnya desentralisasi sebagai asas penyelenggaraan pemerintahan daerah didasarkan pada pertimbangan, bahwa Negara Indonesia memiliki wilayah yang begitu luas, sehingga sulit menyelenggarakan pemerintahan secara efektif, jika menggunakan sistem sentralisasi (Josef Riwu Kaho, 1998, 9-11). Selain itu, faktor-faktor yang mendukung diterapkannya desentralisasi tersebut adalah:

- Keberagaman budaya, banyaknya macam suku, berbagai kepercayaan yang dianut serta beberapa macam unsur lainnya yang mewarnai cara hidup bangsa Indonesia dengan keistimewaannya masing-masing. Semuanya itu hanya dapat saling menunjang dalam penyelenggaraan pemerintahan, apabila dilakukan dengan sistem desentralisasi, karena tidak mungkin mengatur perbedaan golongan dalam suatu penyelenggaraan pemerintahan yang 
seragam (Muchsan dalam M. Arif Nasution et.al., 2000, 85);

- Dihormatinya sendi-sendi pokok pemerintahan asli Indonesia, seperti: otonomi, kekeluargaan, permusyawaratan, dan kebersamaan (kegotongroyongan) diantara para warga masyarakat dalam menyelesaikan dan memutus suatu persoalan sebagaimana yang biasa dilakukan oleh pemerintah di tingkat bawah (Riswandha Imawan dalam Jurusan Ilmu Pemerintahan Fakultas Ilmu Sosial dan Ilmu Politik Universitas Gadjah Mada, 2003, 330);

- Untuk mencapai pemerintahan yang efektif dan efisien. Hal ini didasarkan pada pemikiran bahwa semakin dekat penyelenggaraan pemerintahan dengan masyarakat, maka menambah efektivitas pelayanan kepada masyarakat, karena diharapkan adanya ketepatan dan kecepatan pelayanan (Howard Elcock, 2005, 69);

- Demi terlaksananya demokrasi (Bagir Manan, 2004, 59), dengan sebanyak-banyaknya mengikut sertakan masyarakat dalam proses pemerintahan. Karena setiap daerah terdapat keadaan khusus dan masing-masing masyarakat mempunyai kebutuhan yang berbeda-beda, maka sebaiknya pemenuhan kebutuhannya juga diserahkan kepada daerah itu sendiri.

Secara umum, maksud dianutnya sistem desentralisasi dalam penyelenggaraan pemerintahan negara, antara lain:

- Untuk mencegah penumpukan kekuasaan (Irawan Soejito, 1994, 27), kewenangan dan masalah pada satu pihak atau untuk membatasi kekuasaan pemerintah pusat baik dalam hal penyelenggaraan urusan-urusan tertentu maupun pengaturannya;

- Dalam rangka pendemokrasian, yakni mendidik dan melatih rakyat untuk ikut serta baik aktif maupun pasif terhadap masalah-masalah pemerintahan dan kemasyarakatan, sehingga rakyat tidak merasa sebagai obyek, namun se- bagai subyek dalam pelaksanaan pemerintahan dan pembangunan (Haryanto dalam Jurusan Ilmu Pemerintahan Fakultas Ilmu Sosial dan Ilmu Politik Universitas Gadjah Mada, 2003, 318);

- Untuk kelancaran pemerintahan guna mencapai hasil yang efektif dan efisien (Cornelis Lay dalam Jurusan Ilmu Pemerintahan Fakultas Ilmu Sosial dan Ilmu Politik Universitas Gadjah Mada, 2003, 18), karena urusan-urusan yang kiranya bersifat lokal, secara langsung dapat diselenggarakan oleh masyarakat dan pemerintah daerah sendiri;

- Untuk memberikan perhatian sepenuhnya terhadap hal-hal khusus bagi daerah sesuai dengan keadaan geografis, penduduk, kegiatan ekonomi, corak budaya serta latar belakang sejarahnya. Di samping itu, penyelenggaraan urusan-urusan dan pengaturannya akan dapat disesuaikan dengan aspirasi masyarakat, karena pemerintah daerah tersebut dapat langsung berhubungan dengan masyarakat setempat;

- Ikut mempercepat berhasilnya pembangunan, khususnya di bidang ekonomi, karena usahausaha pembangunan yang dilaksanakan di daerah akan lebih banyak mengikutsertakan masyarakat di lingkungannya (Riyadi dan Deddy Supriady Bratakusumah, 2004, 333);

- Untuk lebih meningkatkan kesadaran bernegara dan berpemerintahan bagi rakyat, karena dekatnya hubungan antara pemerintah daerah dengan masyarakat setempat, sekaligus hal ini untuk menunjukkan pada masyarakat akan eksistensi pemerintah daerah (Janice Morphet, 2008, 41).

Sebagai konsekwensi dari sistem pemerintahan yang didesentralisasikan ini, maka pemerintah pusat harus menyerahkan sebagian urusan kepada daerah otonom dan daerah otonom diberikan kewenangan untuk mengatur dan mengurus urusan rumah tangganya atas inisiatif sendiri se- 
suai dengan keadaan dan kebutuhannya. Pemerintah pusat atau pemerintah di atasnya pada dasarnya tidak lagi berhak mencampuri penyelenggaraan urusan tersebut (Ateng Syafrudin (I), 1983, 910). Kaitannya dengan penyelenggaraan otonomi daerah di Indonesia saat ini, otonomi diberikan kepada daerah (otonom) dengan kewenangan yang seluas-luasnya sebagaimana tertuang dalam Pasal 18 ayat (5) UUD 1945, kecuali urusan pemerintahan yang menjadi urusan Pemerintah Pusat.

Kewenangan untuk melaksanakan otonomi yang seluas-luasnya diwujudkan dalam bentuk kewenangan mengatur dan mengurus semua urusan pemerintahan di luar yang menjadi urusan Pemerintah Pusat, dalam rangka membuat kebijakan daerah untuk memberikan layanan, peningkatan peran serta, prakarsa, dan pemberdayaan masyarakat dengan tujuan untuk meningkatkan kesejahteraan masyarakat. Penjelasan umum UndangUndang Nomor 23 Tahun 2014 digariskan bahwa pemberian otonomi seluas-luasnya kepada daerah dilaksanakan berdasarkan prinsip negara kesatuan. Dalam negara kesatuan, kedaulatan hanya ada pada pemerintahan negara atau pemerintahan nasional dan tidak ada kedaulatan pada daerah. Oleh karena itu, seluas apapun tonomi yang diberikan kepada daerah, tanggung jawab akhir penyelenggaraan pemerintahan daerah akan tetap ada di tangan Pemerintah Pusat. Pemerintahan daerah dalam negara kesatuan merupakan satu kesatuan dengan pemerintahan nasional. Sejalan dengan itu, kebijakan yang dibuat dan dilaksanakan oleh daerah merupakan bagian integral dari kebijakan nasional. Pembedanya adalah terletak pada bagaimana memanfaatkan kearifan, potensi, inovasi, daya saing, dan kreativitas daerah untuk mencapai tujuan nasional tersebut di tingkat lokal yang pada gilirannya akan mendukung pencapaian tujuan nasional secara keseluruhan.

Oleh karena itu, untuk mengimbangi pemberian otonomi yang seluas-luasnya, maka sebagai konsekwensinya adalah hak dan kewenangan yang dimiliki daerah (otonom) dalam melaksanakan tugas dan kewajibannya diarahkan untuk mencapai tujuan pemberian otonomi tersebut, yakni untuk mewujudkan peningkatan kesejahteraan masyarakat, pelayanan umum kepada masyarakat yang semakin baik, dan terciptanya daya saing daerah. Atas dasar pemikiran di atas, maka prinsip-prinsip pemberian otonomi daerah harus memperhatikan aspek demokrasi, keadilan, pemerataan, serta potensi dan keanekaragaman daerah.

Salah satu tujuan kebijakan desentralisasi dan otonomi daerah adalah untuk menjadikan pemerintah lebih dekat dengan rakyatnya, sehingga pelayanan pemerintah dapat dilakukan dengan lebih efisien dan efektif. Hal ini didasarkan pada asumsi bahwa pemerintah kabupaten dan kota memiliki pemahaman yang lebih baik mengenai kebutuhan dan aspirasi masyarakat daerah daripada pemerintah pusat. Meskipun demikian, semua elemen masyarakat yang ada di daerah perlu diperkuat untuk menjamin jalannya proses pemerintahan yang bersih dan bertanggung jawab.

Konteks kewenangan untuk mengatur urusan rumah tangga yang sudah menjadi otonomi daerah tersebut, maka penyelenggaraan urusan pemerintahan daerah harus diatur oleh pemerintah daerah dan DPRD dalam bentuk perda. Untuk menjalankan urusan pemerintahan konkuren yang menjadi kewenangan daerah (yang menjadi otonomi daerah) dan tugas pembantuan, daerah berwenang membentuk perda. Sebagaimana ditentukan dalam Pasal 236 ayat (3), dan (4) UndangUndang Nomor 23 Tahun 2014, materi muatan yang menjadi ruang lingkup pengaturan dalam perda meliputi:

- Penyelenggaraan otonomi daerah dan tugas pembantuan;

- Penjabaran lebih lanjut ketentuan peraturan perundang-undangan yang lebih tinggi;

- Materi muatan lokal (kearifan lokal) sesuai dengan ketentuan peraturan perundangundangan. 
Perda sebagai produk hukum yang dibentuk oleh DPRD dengan persetujuan bersama kepala daerah merupakan salah satu jenis peraturan perundang-undangan. Sesuai dengan Pasal 7 UndangUndang Nomor 12 Tahun 2011 tentang Pembentukan Peraturan Perundang-undangan, perda secara hierarkhi ditempatkan dibawah peraturan presiden. Menurut A. Hamid S. Attamimi (A. Hamid S. Attamimi (II), 1992, 1), peraturan perundang-undangan ialah peraturan negara, di tingkat pusat dan di tingkat daerah, yang dibentuk berdasarkan kewenangan perundang-undangan, baik kewenangan itu yang bersifat atribusi maupun bersifat delegasi. Sementara itu, D.W.P. Ruiter (D.W.P. Ruiter dalam A. Hamid S. Attamimi (III), 1990, 314-316) memasukkan tiga unsur yang harus terdapat dalam peraturan perundang-undangan (wet in materiele zin), yaitu: pertama, merupakan norma hukum yang setidak-tidaknya memuat salah satu diantara empat sifat, yakni bersifat: perintah, larangan, pengijinan/pembolehkan, pembebasan; kedua, norma hukum tersebut berlaku keluar, maksudnya adalah norma hukum tersebut ditujukan kepada rakyat/publik, baik dalam hubungan antar sesamanya maupun antara rakyat dengan pemerintah. Jadi bukan norma yang mengatur hubungan antar bagian-bagian dalam organisasi pemerintahan. Ketiga, norma tersebut bersifat umum dalam arti luas, maksudnya adalah norma yang dibentuk ditujukan kepada orang atau khalayak yang tidak tertentu dan mengatur hal-hal yang tidak tertentu pula. Dengan kata lain, norma tersebut bersifat umum-abstrak.

Dengan demikian, yang dapat dimasukkan ke dalam peraturan perundang-undangan adalah:

1) Norma hukum tersebut merupakan peraturan negara baik di tingkat pusat maupun di tingkat daerah;

2) Dibentuk oleh lembaga negara atau pejabat yang berwenang;

3) Berdasarkan kewenangan perundangundangan, baik kewenangan yang bersifat atribusi maupun bersifat delegasi;
4) Mengikat secara umum, dalam arti norma tersebut berlaku keluar;

5) Isi norma tersebut, salah satu atau seluruhnya bersifat perintah, larangan, pengijinan/pembolehan, pembebasan;

6) Bersifat umum-abstrak.

Perda sebagai instrumen kepala daerah dan DPRD dalam menjalankan pemerintahan daerah, khususnya menjalankan urusan pemerintahan konkuren yang menjadi otonomi daerah agar tidak menyimpang, apalagi bertentangan dengan kebijakan nasional, Pasal 250 Undang-Undang Nomor 23 Tahun 2014 telah memberikan rambu-rambunya, yaitu perda yang dibentuk dilarang:

1) Bertentangan dengan ketentuan peraturan perundang-undangan yang lebih tinggi;

2) Kepentingan umum; dan

3) Kesusilaan.

Sementara untuk kriteria kepentingan umum ditentukan jika:

a) Terganggunya kerukunan antar warga masyarakat;

b) Terganggunya akses terhadap pelayanan publik;

c) Terganggunya ketenteraman dan ketertiban umum;

d) Terganggunya kegiatan ekonomi untuk meningkatkan kesejahteraan masyarakat; dan/ atau

e) Diskriminasi terhadap suku, agama dan kepercayaan, ras, antar golongan, dan gender.

Dengan adanya kejelasan batasan dan kriteria dalam pembentukan perda tersebut, diharapkan daerah, khususnya kabupaten dan kota dapat menyelaraskan materi muatannya dengan kebijakan nasional. Begitu juga sebaliknya, jika terjadi penyimpangan materi muatan, maka sudah jelaslah ukuran untuk melakukan pembatalan terhadap perda yang sudah ditetapkan. 


\section{Prinsip Negara Hukum}

Pasal 1 ayat (3) UUD 1945 menyatakan Negara Indonesia adalah negara hukum. Banyak ahli memberikan indikator untuk menentukan sebuah negara dikategorikan sebagai negara hukum, diantaranya pendapat Van Wikj \& Konijnenbelt (H.D. Van Wijk \& W. Konijnenbelt dalam A. Hamid S. Attamimi (III), 1990, 311) yang menentukan empat kriteria, yaitu:

1) Pemerintahan menuruthukum (wetmatig bestuur), dengan bagian-bagiannya tentang kewenangan yang dinyatakan dengan tegas, tentang perlakuan yang sama, dan tentang kepastian hukum;

2) Hak-hak asasi;

3) Pembagian kekuasaan, dengan bagian-bagiannya tentang struktur kewenangan atau desentralisasi dan tentang pengawasan dan kontrol;

4) Pengawasan oleh kekuasaan peradilan.

Sementara pendapat yang tidak jauh berbeda disampaikan oleh Zippelius (R. Zippelius dalam A. Hamid S. Attamimi (III), 1990, 311) tentang negara berdasar atas hukum, yaitu:

a) Pemerintahan menurut hukum;

b) Jaminan terhadap hak-hak asasi;

c) Pembagian kekuasaan;

d) Pengawasan yustisial terhadap pemerintah.

Dari dua pendapat di atas dapat disimpulkan bahwa indikator sebuah negara dimasukkan sebagai negara hukum jika memenuhi empat unsur, yaitu: penyelenggaraan pemerintahan berdasarkan hukum (asas legalitas), penghormatan dan jaminan terhadap hak-hak asasi manusia, adanya pembagian dalam kekuasaan negara, dan pengawasan oleh pengadilan, terutama pengadilan tata usaha negara terhadap tindak pemerintahan. Tentu nanti dalam prakteknya penentuan klasifikasi negara hukum terhadap pemenuhan indikator tersebut akan melahirkan negara hukum dalam arti formal yang baru dipenuhi pada tingkat pengaturan dalam norma hukum dan negara hukum dalam arti materiil, yaitu pemenuhan unsur-unsur negara hukum yang terimplementasikan dalam kehidupan berbangsa dan bernegara, yang terakhir inilah kebanyakan negara akan terus mengalami pasang surut dalam pelaksanaannya.

Berdasarkan indikator pertama negara hukum bahwa segala tindakan dalam penyelenggaraan pemerintahan negara harus berdasar atas hukum, maka dalam kaitannya dengan pembatalan perda, karena dinilai bertentangan dengan ketentuan peraturan perundang-undangan yang lebih tinggi, dan/atau bertentangan dengan kepentingan umum, dan/atau bertentangan dengan kesusilaan, maka perlu untuk memperhatikan ketentuan Pasal 24A ayat (1) UUD 1945, yaitu "Mahkamah Agung berwenang mengadili pada tingkat kasasi, menguji peraturan perundangundangan di bawah undang-undang terhadap undang-undang, dan mempunyai wewenang lainnya yang diberikan oleh undang-undang". Pengaturan demikian ini sebenarnya secara historis pernah diatur dalam Undang-Undang Nomor 14 Tahun 1970 tentang Ketentuan-ketentuan Pokok Kekuasaan Kehakiman Pasal 26 ayat (1), juga Pasal 11 ayat (2) Undang-Undang Nomor 4 Tahun 2004 tentang Kekuasaan Kehakiman sebagai pengganti Undang-Undang Nomor 14 Tahun 1970.

Saat ini undang-undang yang mengatur tentang pengujian peraturan perundang-undangan di bawah undang-undang terhadap undang-undang adalah Undang-Undang Nomor 48 Tahun 2009 tentang Kekuasaan Kehakiman sebagai pengganti Undang-Undang Nomor 4 Tahun 2004 yang diatur dalam Pasal 20 ayat (2), dan Undang-Undang Nomor 12 Tahun 2011, Pasal 9 ayat (2).

Landasan hukum di atas jelas bahwa pranata judicial review peraturan perundang-undangan di bawah undang-undang terhadap undang-undang sudah lama dikenal dan diatur dalam undangundang sebelum memperoleh pengaturan lebih 
kuat dalam UUD 1945. Di samping itu, judicial review akan memperkuat keberadaan prinsip negara hukum sebagaimana implementasi dari indikator keempat, yaitu pengawasan oleh lembaga peradilan terhadap tindakan pemerintah, sehingga dalam kehidupan kenegaraan akan tercipta prinsip check and balances sebagai inti dari tindakan yang menjauhkan dari tindakan sewenang-wenang.

Yang menjadi persoalan adalah ketika judicial review tersebut diterapkan dalam sebuah negara kesatuan yang mempunyai prinsip unitary/eenheid bahwa dalam negara kesatuan seluruh wilayah negara merupakan satu kesatuan, termasuk di dalamnya satu kesatuan sistem hukum nasionalnya, bagaimana jika produk hukum yang di hasilkan oleh daerah tidak sejalan dengan kebijakan nasional dan apabila sebagian besar produk hukum di daerah disinyalir bertentangan dengan peraturan perundang-undangan atau kebijakan nasional, tidak bisa dibayangkan bagaimana Mahkamah Agung menyelesaikan persoalan ini. Namun demikian, karena NKRI sejak lama sudah berkomitmen untuk menegakkan negara hukum, maka prinsipprinsipnya harus dihormati dan dicarikan solusinya dengan tetap mengindahkan prinsip negara kesatuan dalam rangka menjaga keutuhan wilayah dan mengawal tujuan nasionalnya.

Atas dasar itulah, Pemerintah Pusat (eksekutif) dapat melakukan secara efektif dan cermat melalui pengawasan preventif dalam bentuk executive $a b-$ stract preview terhadap rancangan perda yang belum diperlakukan kepada publik. Di wilayah inilah Pemerintah Pusat atau pemerintah di atasnya yang diberikan kewenangan untuk melakukan pengawasan terhadap rancangan produk hukum yang masuk ke dalam peraturan perundangudangan yang bisa dilakukan secara detail melalui sebuah mekanisme yang diatur dalam peraturan perundang-undangan. Jika produk hukum seperti perda sudah diberlakukan dan mengikat umum, selanjutnya di kemudian hari tidak lagi sejalan dengan kebijakan nasional, maka hanya bisa dilakukan melalui judicial review oleh lembaga atau kekuasaan lain atau secara internal dilakukan melalui legislative review atau executive review dengan cara menghasilkan peraturan baru untuk mencabut atau mengganti peraturan lama.

\section{Mekanisme Pengendalian Pembentukan Perda}

Secara yuridis, pengaturan tentang mekanisme pembentukan peraturan perundangundangan saat ini relatif sudah memadai untuk dapat mengendalikan produk hukum yang dihasilkan oleh lembaga atau pejabat yang berwenang membentuk peraturan perundang-undangan mulai dari tingkat bawah sampai ke atas, sehingga diharapkan peraturan yang ada di bawah tidak boleh bertentangan dengan peraturan yang ada di atasnya. Pengaturan yang mendasari pembentukan peraturan perundang-undangan tersebut adalah Undang-Undang Nomor 12 Tahun 2011 tentang Pembentukan Peraturan Perundang-undangan. Sebagai tindak lanjut dari Undang-Undang Nomor 12 Tahun 2011, telah dikeluarkan Peraturan Presiden Nomor 87 Tahun 2014 tentang Perturan Pelaksanaan Undang-Undang Nomor 12 Tahun 2011 tentang Pembentukan Peraturan Perundangundangan. Kemudian khusus untuk pembentukan produk hukum daerah, perda dan produk hukum daerah lainnya, telah dikeluarkan Peraturan Menteri Dalam Negeri Nomor 80 Tahun 2015.

Peraturan Menteri Dalam Negeri Nomor 80 Tahun 2015 inilah pengawasan preventif dalam bentuk executive abstract preview terhadap rancangan perda telah memperoleh pengaturan relatif rinci, sehingga harapan prinsip negara kesatuan tetap terjaga dan prinsip negara hukum dengan memberikan ruang judicial review tetap terbuka. Setidaktidaknya ada dua pengelompokan pengawasan preventif dalam bentuk executive abstract preview terhadap rancangan perda sebelum diberlakukan kepada masyarakat sebagai pengendalian substantif perda yang dibentuk oleh daerah, khususnya kabupaten/kota: pertama, semua rancangan perda 
yang dievaluasi; dan kedua, semua rancangan perda yang tidak termasuk dievaluasi.

Pertama, semua rancangan perda yang dievaluasi sebanya 8 (delapan) bidang, yaitu rancangan perda tentang:

- RPJPD;

- RPJMD;

- Anggaran pendapatan dan belanja daerah (APBD), perubahan APBD, pertanggungjawaban pelaksanaan APBD;

- Pajak daerah;

- Retribusi daerah;

- Tata ruang daerah;

- Pembangunan industri; dan

- Pembentukan, penghapusan, serta penggabungan dan/atau perubahan status desa menjadi kelurahan atau kelurahan menjadi desa.

Delapan rancangan perda kabupaten/kota di atas yang sudah disetujui bersama antara bupati/ walikota dengan DPRD harus disampaikan oleh bupati/walikota kepada gubernur sebagai wakil Pemerintah Pusat paling lama 3 (tiga) hari sebelum ditetapkan oleh bupati/walikota. Gubernur sebagai wakil Pemerintah Pusat setelah menerima rancangan perda tersebut melakukan evaluasi terhadap materi muatan rancangan perda tersebut yang hasilnya disampaikan dalam bentuk keputusan gubernur kepada Mendagri untuk dilakukan pengkajian. Khusus untuk rancangan perda tentang pajak daerah dan retribusi daerah, gubernur sebagai wakil Pemerintah Pusat berkonsultasi dengan Mendagri melalui Direktur Jenderal Bina Keuangan Daerah dan selanjutnya Mendagri berkoordinasi dengan Menteri Keuangan terhadap rancangan perda tersebut. Sedangkan untuk rancangan perda tentang tata ruang daerah, gubernur sebagai wakil Pemerintah Pusat berkonsultasi dengan Mendagri melalui Direktur Jenderal Bina Pembangunan Daerah dan selanjutnya Mendagri berkoordinasi dengan Menteri yang menyelenggarakan urusan pemerin- tahan bidang tata ruang untuk mengkaji rancangan perda tersebut.

Sementara untuk hasil evaluasi terhadap rancangan perda tentang RPJPD, RPJMD, APBD, perubahan APBD, pertanggungjawaban pelaksanaan $\mathrm{APBD}$, pajak daerah, retribusi daerah, tata ruang daerah, pembangunan industri di daerah secara teknis diatur dengan peraturan Mendagri. Sedangkan yang menyangkut rancangan perda tentang pembentukan, penghapusan, serta penggabungan dan/atau perubahan status desa menjadi kelurahan atau kelurahan menjadi desa didasarkan pada peraturan perundang-undangan yang mengatur tentang desa.

Dalam Peraturan Mendagri Nomor 80 Tahun 2015 ini memang tidak ditentukan berapa lama waktu yang diberikan untuk melakukan evaluasi rancangan perda tersebut, yang diatur hanya waktu yang disediakan kepada bupati/walikota dan DPRD untuk menyempurnakan atau menyesuaikan hasil evaluasi dari rancangan perda tersebut paling lama 7 (tujuh) hari sejak rancangan perda diterima dari gubernur sebagai wakil Pemerintah Pusat dan selanjutnya bupati/walikota mengajukan permohonan kepada gubernur sebagai wakil Pemerintah Pusat untuk memperoleh nomor registrasi setelah rancangan perda tersebut disempurnakan.

Kedua, semua rancangan perda yang tidak termasuk dievaluasi, di luar 8 (delapan) rancangan perda di atas harus dilakukan pembinaan dalam bentuk fasilitasi oleh gubernur sebagai wakil Pemerintah Pusat terhadap rancangan perda kabupaten/ kota yang disampaikan bupati/walikota sebelum dilakukan persetujuan bersama antara DPRD dengan bupati/walikota. Fasilitasi ini tidak berlaku untuk rancangan perda yang dievaluasi, karena memang sudah mempunyai mekanisme tersendiri. Gubernur sebagai wakil Pemerintah Pusat diberikan kesempatan 15 (lima belas) hari setelah rancangan perda tersebut diterima untuk dipelajari untuk dapat memberikan masukan terhadap ran- 
cangan perda tersebut. Apabila waktu 15 (lima belas) hari tersebut tidak dimanfaatkan untuk fasilitasi, maka rancangan perda tersebut dapat dilanjutkan oleh bupati/walikota untuk dimintakan persetujuan bersama dengan DPRD.

Persetujuan bersama antara bupati/walikota dengan DPRD tidak otomatis rancangan perda yang tidak termasuk dievaluasi ini bisa langsung ditetapkan dan diberlakukan kepada masyarakat, karena masih ada satu tahapan lagi, yaitu wajib disampaikan kepada gubernur sebagai wakil Pemerintah Pusat 3 (tiga) hari sejak bupati/walikota menerima rancangan perda tersebut dari pimpinan DPRD untuk memperoleh nomor registrasi perda.

Mekanisme pembentukan perda di kabupaten/kota sebagaimana diuraikan di atas, pemerintah di atasnya relatif memiliki ruang yang cukup untuk melakukan evaluasi melalui pengawasan preventif dalam bentuk executive abstract preview terhadap rancangan perda sebelum diberlakukan kepada masyarakat sebagai pengendalian substantif perda yang dibentuk oleh daerah. Dengan demikian, prinsip negara kesatuan dan prinsip negara hukum dapat ditegakkan secara bersama-sama.

\section{Penutup}

Indonesia sebagai negara kesatuan yang berbentuk republik seperti ditentukan dalam Pasal 1 ayat (1) UUD 1945 telah ditetapkan secara final dan tidak dapat dilakukan perubahan sebagaimana diatur dalam Pasal 37 ayat (5) UUD 1945 mempunyai konsekwensi bahwa segala kekuasaan dalam penyelenggaraan pemerintahan negara pada akhirnya merupakan tanggung jawab Pemerintah Pusat, dalam hal ini adalah Presiden Republik Indonesia. Namun karena luasnya wilayah, besarnya urusan pemerintahan untuk memenuhi kebutuhan masyarakat, dan beragamnya aspek kehidupan dalam wilayah NKRI, maka dibentuklah daerahdaerah otonom berupa provinsi-provinsi dan kabupaten-kabupaten/kota-kota.
Keberadaan provinsi dan kabupaten/kota di Indonesia pada hakekatnya adalah untuk mempercepat terwujudnya kesejahteraan masyarakat melalui peningkatan pelayanan, pemberdayaan, peran masyarakat, dan daya saing daerah berdasarkan prinsip demokrasi, pemerataan, keadilan, dan kekhasan daerah. Oleh karena itu, daerah diberikan otonomi seluas-luasnya untuk menyelenggarakan urusan pemerintahan yang menjadi otonominya (kewenangannya). Untuk menyelenggarakan pemerintahan daerah tersebut, pemerintah daerah (bupati/walikota) dan DPRD kabupaten/kota diberikan kewenangan untuk membentuk perda kabupaten/kota yang menjadi lingkup kewenangannya.

Dengan memperhatikan prinsip negara kesatuan bahwa keberadaan daerah kabupaten/kota merupakan bagian tak terpisahkan dengan NKRI, termasuk produk hukum daerah, khususnya perda kabupaten/kota menjadi satu kesatuan sistem hukum nasional, maka pembentukan perda kabupaten/kota harus juga memperhatikan prinsip negara hukum bahwa sebelum perda diberlakukan kepada masyarakat harus dilakukan evaluasi oleh Pemerintah Pusat atau pemerintah di atasnya melalui pengawasan preventif dalam bentuk executive abstract preview terhadap rancangan perda tersebut dan ketika perda sudah diberlakukan kepada masyarakat, jika dalam perjalannya terdapat ketidaksesuaian dengan kebijakan nasional, maka pengujiannya harus dilakukan oleh lembaga peradilan melalui mekanisme judicial review, kecuali jika secara internal melalui kewenangannya dilakukan legislative review atau executive review dengan cara menghasilkan peraturan baru untuk mencabut atau mengganti peraturan lama.

\section{DAFTAR PUSTAKA}

\section{Buku}

Arif Nasution, M. et.al., 2000, Demokratisasi dan Problema Otonomi Daerah, Cetakan Pertama, Mandar Maju, Bandung. 
Ateng Syafrudin (I), 1983, Pemerintah Daerah dan Pembangunan, Sumur, Bandung.

Bagir Manan, 2004, Menyongsong Fajar otonomi Daerah, Cetakan Ketiga, Pusat Studi Hukum Fakultas Hukum UII, Yogyakarta

Howard Elcock, 2005, Local Government, policy and management in local authorities, Third edition, Routledge, New York.

Irawan Soejito, 1994, Hubungan Pemerintah Pusat dan Pemerintah Daerah, Cetakan II, Bina Aksara, Jakarta.

Janice Morphet, 2008, Modern Local Government, First published, SAGE Publication, London.

Joeniarto, R. 1982, Perkembangan Pemerintah Lokal, Alumni, Bandung.

Josef Riwu Kaho, 1998, Prospek Otonomi Daerah di Negara Republik Indonesia, Cetakan II, Rajawali, Jakarta.

Jurusan Ilmu Pemerintahan Fakultas Ilmu Sosial dan Ilmu Politik Universitas Gadjah Mada, 2003, Kompleksitas Persoalan otonomi daerah di Indonesia, Cet. I, Pustaka Pelajar, Yogyakarta.

Kelsen, Hans. 1973. General Theory of Law and State, Russell \& Russell, New York.

Lubis, M. Solly. 1986, Pergeseran Garis Politik dan perundang-undangan Mengenai pemerintahan Daerah, Cet. IV, Alumni, Bandung.

Riyadi dan Deddy Supriady Bratakusumah, 2004, Perencanaan Pembangunan Daerah, strategi menggali potensi dalam mewujudkan otonomi daerah, Cetakan Kedua, Gramedia Pustaka Utama, Jakarta.

Van Wijk, H.D. \& W. Konijnenbelt, 1988, Hoofdstukken van Administratiefrecht, Culemborq, Lemma, hal. 55 dalam A. Hamid S. Attamimi (III).

Zippelius, R. 1973, Allgemeine Staatslehre (politik wissenschaft), Munchen, Beck, Cet. IV, hal. 168 dalam A. Hamid S. Attamimi (III).

\section{Karya Tidak di Publikasikan}

Hamid S. Attamimi, A. (II), 1992, Fungsi Presiden dan Fungsi DPR di Bidang Perundang-undangan (pembentukan dan pengujian peraturan perundang-undangan menurut UUD 1945), Makalah disampaikan pada acara Dies Natalis Fakultas Hukum Universitas Sriwijaya ke-35 pada tanggal 5 Desember 1992, Palembang.

Hamid S. Attamimi, A. (III), 1990, Peranan Keputusan Presiden Republik Indonesia dalam Penyelenggaraan Pemerintahan Negara, suatu studi analisis mengenai Keputusan Presiden yang berfungsi pengaturan dalam kurun waktu pelita I - pelita IV, Disertasi, Universitas Indonesia.

\section{Peraturan Perundang-Undangan}

Undang-Undang Dasar Negara Republik Indonesia Tahun 1945.

Undang-Undang Nomor 14 Tahun 1970 tentang Ketentuan-ketentuan Pokok Kekuasaan Kehakiman.

Undang-Undang Nomor 4 Tahun 2004 tentang Kekuasaan Kehakiman.

Undang-Undang Nomor 48 Tahun 2009 tentang Kekuasaan Kehakiman.

Undang-Undang Nomor 12 Tahun 2011 tentang Pembentukan Peraturan Perundang-undangan.

Undang-Undang Nomor 23 Tahun 2014 tentang Pemerintahan Daerah.

Peraturan Presiden Nomor 87 Tahun 2014 tentang Peraturan Pelaksanaan Undang-Undang Nomor 12 Tahun 2011 tentang Pembentukan Peraturan Perundang-undangan.

Peraturan Menteri Dalam Negeri Nomor 80 Tahun 2015 tentang Pembentukan Produk Hukum Daerah.

Putusan Mahkamah Konstitusi R.I. Nomor 137/PUUXIII/ 2015 tentang Pengujian Terhadap Pasal 251 ayat (2). (3), (4), dan ayat (8) Undang-Undang Nomor 23 Tahun 2014 tentang Pemerintahan Daerah yang diucapkan dalam sidang pleno terbuka pada tanggal 5 April 2017. 